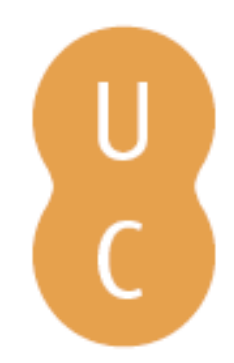

\title{
pompalina
}

\section{Exploring the capability to forecast wildfires: spatial modelling of the Tavira/São Brás de Alportel 2012 wildfire}

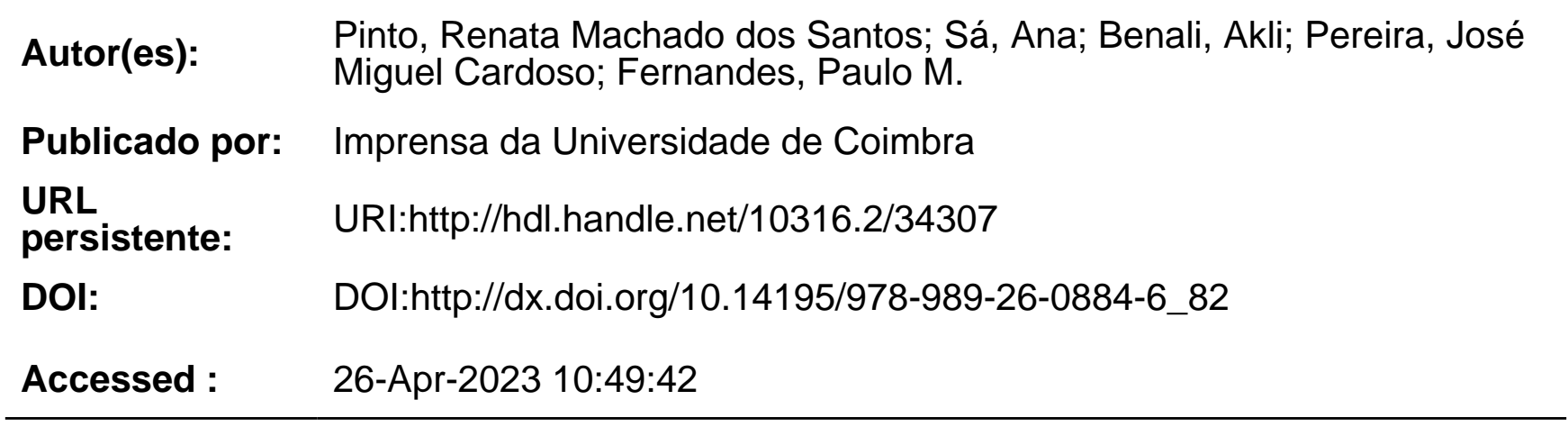

A navegação consulta e descarregamento dos títulos inseridos nas Bibliotecas Digitais UC Digitalis, UC Pombalina e UC Impactum, pressupõem a aceitação plena e sem reservas dos Termos e Condições de Uso destas Bibliotecas Digitais, disponíveis em https://digitalis.uc.pt/pt-pt/termos.

Conforme exposto nos referidos Termos e Condições de Uso, o descarregamento de títulos de acesso restrito requer uma licença válida de autorização devendo o utilizador aceder ao(s) documento(s) a partir de um endereço de IP da instituição detentora da supramencionada licença.

Ao utilizador é apenas permitido o descarregamento para uso pessoal, pelo que o emprego do(s) título(s) descarregado(s) para outro fim, designadamente comercial, carece de autorização do respetivo autor ou editor da obra.

Na medida em que todas as obras da UC Digitalis se encontram protegidas pelo Código do Direito de Autor e Direitos Conexos e demais legislação aplicável, toda a cópia, parcial ou total, deste documento, nos casos em que é legalmente admitida, deverá conter ou fazer-se acompanhar por este aviso.

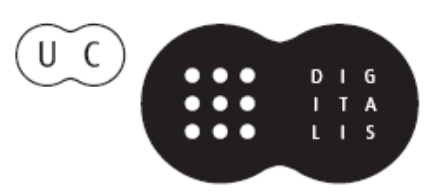




\section{ADVANCES IN}

Forest Fire

\section{RESEARCH}

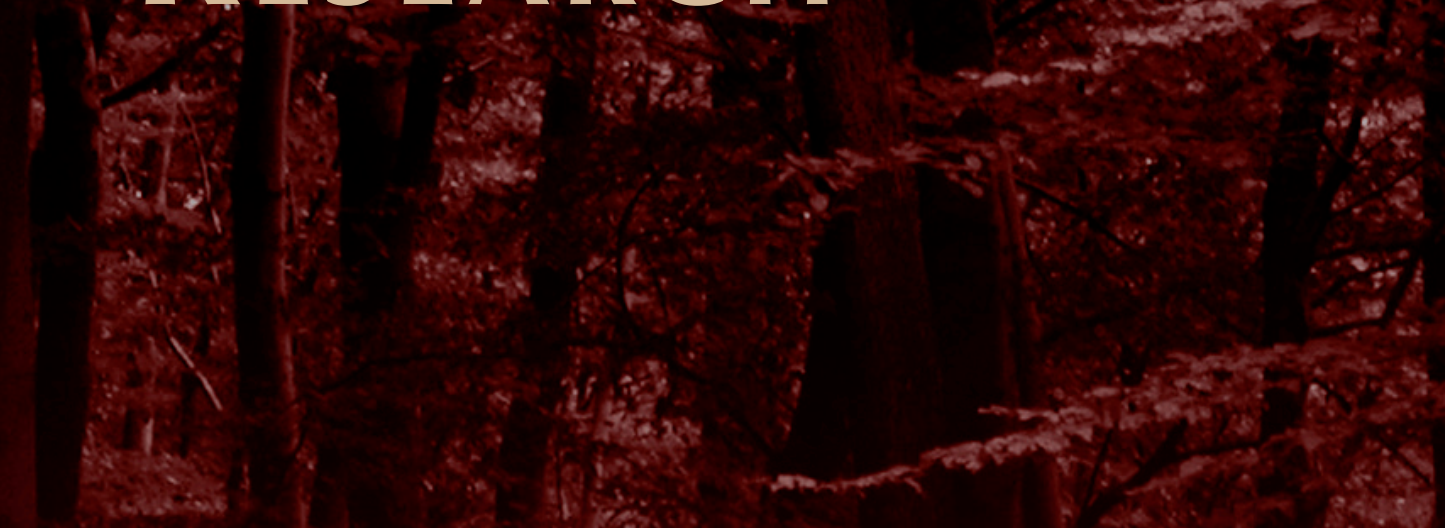

\section{DOMINGOS XAVIER VIEGAS}

\section{EDITOR}




\title{
Exploring the capability to forecast wildfires: spatial modelling of the Tavira/São Brás de Alportel 2012 wildfire
}

\author{
Renata Machado dos Santos Pinto ${ }^{a}$, Ana Sáa ${ }^{\text {, Akli Benali }}{ }^{a}$, José Miguel Cardoso Pereira ${ }^{a}$, Paulo M. \\ Fernandes $^{\mathrm{b}}$ \\ ${ }^{a}$ Centro de Estudos Florestais, Tapada da Ajuda, Instituto Superior de Agronomia, 1349-017 \\ Lisboa, Portugal, renatamspinto@sapo.pt \\ ${ }^{b}$ Centro de Investigação e de Tecnologias Agro-Ambientais e Biológicas, Universidade de Trás-os- \\ Montes e Alto Douro (UTAD), Apartado 1013, 5001-801 Vila Real, Portugal
}

\begin{abstract}
We explore the forecasting capability of two spatially-explicit fire spread models, HFire and FARSITE, and the potential of combining fire spread models and satellite data. A well-documented wildfire that occurred in southern Portugal in July 2012 (approx. 24800ha) is investigated. Accuracy of the fire spread models is evaluated by comparing simulated fire spread perimeters with the reported spatio-temporal distribution of the wildfire event, at three different time steps. Results show good agreement between the simulated and observed burned area perimeters (Sørensen metric). Some differences are found in specific fire propagation time intervals. When simulations are initialized using the reported ignition point, FARSITE progressively shows an underestimation of the fire's time of arrival, whereas HFire shows an overestimation for some time steps. Initializing fire-spread simulations with active-fires ignition points improves time of arrival predictions for some time steps. FARSITE is able to predict abrupt changes in rate of spread and fire line intensity, consistent with the reported information for the wildfire event. Both models show good capability to forecast fire spread. The use of fire spread models with satellite data has great potential since the combination of both improves fire growth and behavior predictions, providing valuable supplementary information to fire management and decision support during large wildfire events.
\end{abstract}

Keywords: HFire, FARSITE, fire spread modelling, satellite active-fires, fire suppression, MODIS, fire behaviour

\section{Introduction}

Portugal has one of the highest fire incidences in southern Europe with extreme landscape susceptibility to fire, aggravated during the last four decades due to rural abandonment (Pereira et al. 2005). In recent years, catastrophic fires that occurred under extreme weather conditions have challenged the country's fire suppression capabilities.

In Portugal, burnt area extent is mainly controlled by two factors: long dry periods without precipitation in late spring and early summer (climate anomaly), and the occurrence of very intense hot and dry spells in days of extreme synoptic conditions (weather anomaly) and in fact, $80 \%$ of the burnt area is due to fire events occurring in 10\% of summer days (Pereira et al. 2005). During the 2003 fire season, extremely anomalous weather conditions were observed, with a devastating sequence of large wildfires resulting in a total of 450.000 ha of burned area, approximately twice the previous highest record (220.000ha in 1998) and four times the 1980-2004 average (Trigo et al. 2006). Future climatic scenarios show an increase in fire risk in the Mediterranean basin (Mouillot et al. 2002; Moriondo et al. 2006; Flannigan et al. 2009). In particular, Portugal is expected to experience a temperature increase in spring and summer and an increase in the frequency of heat waves (Ramos et al., 2011), likely leading to longer and more severe fire seasons with greater incidence of large uncontrolled wildfires.

Predicting fire spread and behaviour during large wildfire events can greatly improve the efficiency of fire suppression, providing valuable information during firefighting activities enabling more efficient resource allocation and implementation of control lines. One of the most effective tools to study how 
the main drivers of wildfire spread and behaviour interact - meteorological conditions, topography and vegetation - is fire spread modelling (Keane et al. 2004).

Recently, some authors have also explored the potential of satellite data to monitor large wildfire events (Smith et al. 2005; Loboda et al. 2007). For example, the MODerate Resolution Imaging Spectroradiometer sensor (MODIS) has been integrated in operational systems to assist fire managers detecting active-fires that are burning at the time of overpass (Lee et al., 2002), providing inter- and intra-daily spatio-temporal distributions of individual wildfire events propagation, which is usually done by post-fire collection of field data and interviews. Coen \& Schroeder (2013) have used spatially remote sensing data to initialize and evaluate coupled weather-wildfire growth model simulations, with improved results from this approach arising from initialization with more current weather analyses and updated maps of fire location.

In this paper, we explore the capability of two spatially-explicit landscape fire spread models - HFire (Petersen et al. 2009) and FARSITE (Finney 1998) - to forecast fire spread and behavior during a large fire event, and the advantage of combining fire-spread modelling with satellite data. Inaccuracies in input data (e.g. maps of surface fuels developed without field validation; inaccurate estimates of canopy cover and crown characteristics) produce errors that propagate during simulations. Combining simulations with satellite-derived active-fires from consecutive MODIS passages can help overcome some of these errors, since simulations are updated in space and time at each passage. The feasibility of these approaches is examined based on the analysis of a well-documented wildfire that occurred in Tavira, southern Portugal in July 2012 (Tavira wildfire hereafter). The performance of both fire spread models is evaluated by comparing the observed fire perimeter with the simulated fire perimeters and the temporal distribution of the Tavira wildfire, derived from the information reported for the event. A performance assessment from the combined use of both tools is also performed.

\section{Methods}

\subsection{Fire spread models}

HFire (Highly Optimized Tolerance Fire Spread Model) (Morais 2001) is a computationally efficient raster-based fire growth model capable of simulating surface fire spread (Rothermel 1972) through shrubland fuels. HFire uses an adaptive time step allowing for the fire to spread into a cell from all neighbouring cells over multiple time steps (contact-based approach). It has been developed to support simulations of single fire events and long-term fire regimes (Petersen at al. 2009; Petersen et al. 2011). FARSITE (Fire Area Simulator) is a two-dimensional deterministic fire growth and behaviour model, developed by the USDA Forest Service, and widely used to simulate wildfire spread (e.g. Keane et al. 2001; Stratton 2004; Loureiro et al. 2006; Arca et al. 2007). FARSITE incorporates a surface fire spread model (Rothermel 1972), and additional crown fire spread, spotting, post-frontal combustion and fire acceleration models. The spatial growth of fire perimeters is based on Huygens' Principle of wave propagation (Finney 1998).

\subsection{Model inputs and parameters}

The variables required for modelling an individual fire event are similar in both fire spread models (Table 1). 
Table 1. List of input variables and outputs for FARSITE and HFire landscape fire spread models.

\begin{tabular}{|c|c|c|}
\hline Inputs types & HFire & FARSITE \\
\hline \multirow{5}{*}{$\begin{array}{l}\text { Landscape } \\
\text { (GIS layers) }\end{array}$} & Elevation $(\mathrm{m})$ & Canopy cover (\%) \\
\hline & Slope $\left(^{\circ}\right)$ & Canopy height (m) \\
\hline & Aspect $\left({ }^{\circ}\right)$ & Canopy base height (m) \\
\hline & Fuel (categories) & Canopy bulk density $\left(\mathrm{kg} \mathrm{m}^{-3}\right)$ \\
\hline & & \multirow{2}{*}{$\begin{array}{l}\text { Fuel (categories) } \\
\text { Fuel model, Fuel rate of spread adjustment }\end{array}$} \\
\hline \multirow[t]{2}{*}{ Fuel } & Fuel model & \\
\hline & $\begin{array}{l}\text { Fuel moisture (10-hr, live } \\
\text { herbaceous, live woody }(\%)\end{array}$ & $\begin{array}{l}\text { Fuel moisture (1-hr, 10-hr, 100-hr, live herbaceous, } \\
\text { live woody) }(\%)\end{array}$ \\
\hline \multirow[t]{4}{*}{ Weather } & & Precipitation (mm) \\
\hline & & Relative humidity (\%) \\
\hline & & Temperature $\left({ }^{\circ} \mathrm{C}\right)$ \\
\hline & & Cloud cover (\%) \\
\hline \multirow[t]{2}{*}{ Winds } & Wind speed $\left(\mathrm{km} \mathrm{h}^{-1}\right)$ & Wind speed $\left(\mathrm{km} \mathrm{h}^{-1}\right)$ \\
\hline & Wind direction $\left(^{\circ}\right)$ & Wind direction $\left({ }^{\circ}\right)$ \\
\hline Ignition & Ignition point & Ignition point \\
\hline \multirow[t]{5}{*}{ Outputs } & Burned area & Fire perimeters \\
\hline & Time of arrival (hours) & Fire behavior parameters: \\
\hline & & \multirow{3}{*}{$\begin{array}{l}\text { Time of arrival }(\mathrm{hr}) \text {; Fire line intensity }\left(\mathrm{kW} \mathrm{m}^{-1}\right) \text {; } \\
\text { Flame length }(\mathrm{m}) \text {; Rate of spread }\left(\mathrm{m} \mathrm{min}^{-1}\right) \text {; Heat per } \\
\text { unit area }\left(\mathrm{kJ} \mathrm{m}^{-2}\right) \text {; Reaction intensity }\left(\mathrm{kW} \mathrm{m}^{-2}\right)\end{array}$} \\
\hline & & \\
\hline & & \\
\hline
\end{tabular}

Aspect, elevation and slope maps were derived from the Digital Elevation Model provided by the Shuttle Radar Topography Mission (90m resolution). Canopy cover was derived from the MODIS tree cover dataset (250m resolution) (DiMiceli et al. 2011).

Fuel maps consisting of the 13 fire behavior fuel models (Anderson 1982) were produced by the Tavira and São Brás de Alportel municipalities, for the Municipal Forest Defense Plan Against Fires.

In order to have the most representative wind data at the time of the fire, wind speed and direction were obtained from the ENEOP2-MJ250 (Exploração de Parques Eólicos SA) station (Viegas et al. 2012). WindNinja (Forthofer et al. 2009) was used to model the prevailing hourly wind inputs, simulating the spatially varying wind fields given the effect of topography. The meteorological data used in this study was collected from the Faz Fato weather station (http://www.wunderground.com/). Temperature, relative humidity and precipitation were summarized on a daily basis, using the time of maximum and minimum temperature. Cloud cover was assumed to be zero for the entire simulation period.

Reference values for live fuel moisture in the dry season for chaparral fuels (Morais 2001) were used for live herbaceous and woody fuels, $50 \%$ and $70 \%$ respectively, in both models. The 10-hr dead fuel moisture, required by HFire in an hourly basis, was estimated using an algorithm based on Nelson's dead fuel moisture model (Nelson, 2000), which determines moisture content of dead and down woody fuels. For FARSITE, initial fuel moistures were set at 5, 8 and 10\% for 1-hr, 10-hr and 100-hr dead fuels respectively. These values were empirically derived from the previous estimates for HFire.

\subsection{Case Study - background and description}

All the descriptive information referred in this section, related with the case study, was obtained from three reports (ANPC 2012; ICNF 2012; Viegas et al. 2012). These reports thoroughly describe the development and behavior of the Tavira wildfire event, providing the qualitative and quantitative information necessary to assess the performance of the fire spread models. 
The Tavira wildfire occurred between the $18^{\text {th }}$ and $21^{\text {st }}$ of July 2012, in the Tavira and São Brás de Alportel municipalities (Figure 1). It burned approximately 24.800 ha, mainly through shrubland (61\% of the affected area), and was one of the largest fires recorded in the last years.

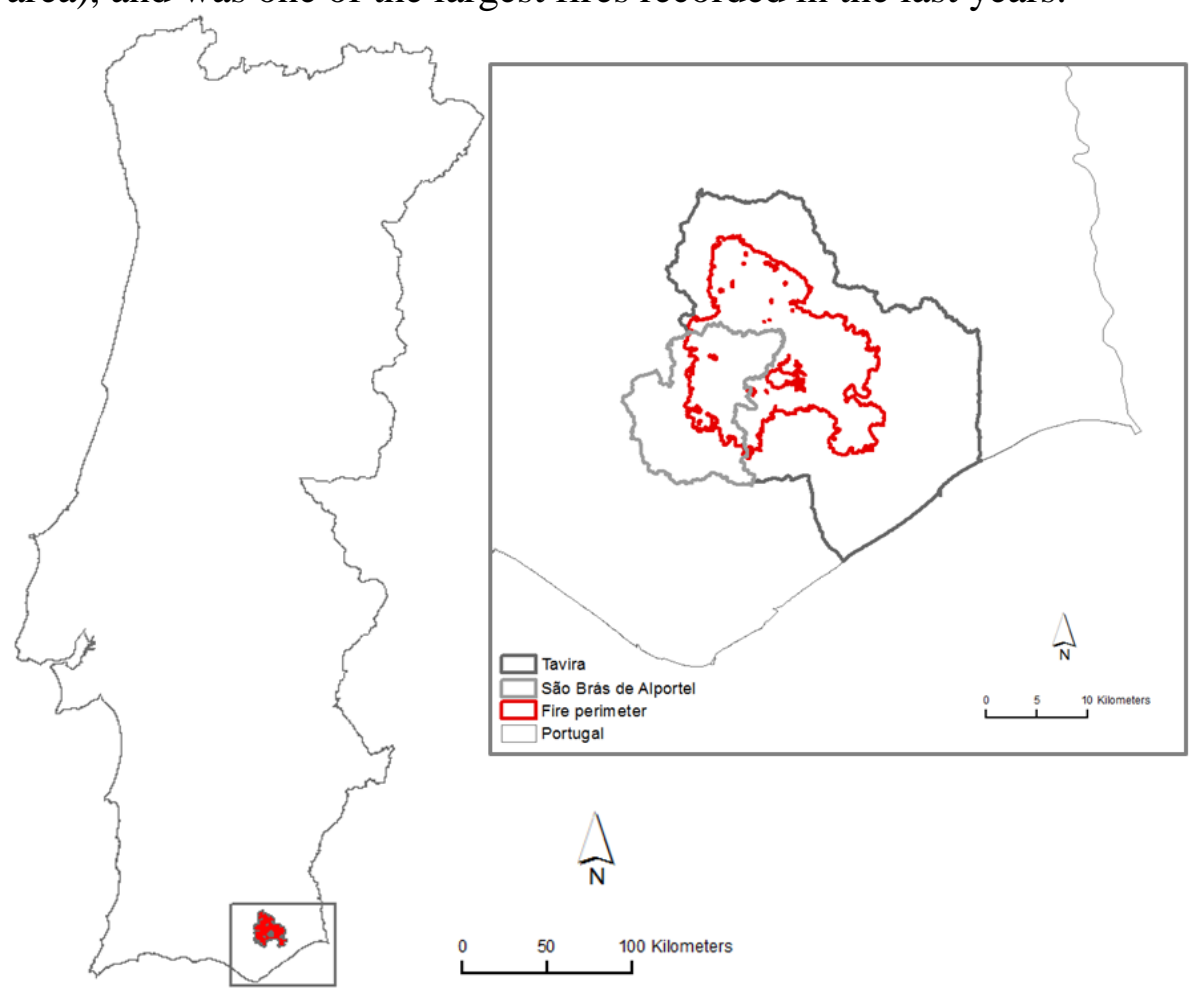

Figure 1. Location of the Tavira Wildfire occurred in July 2012 (Portugal)

The area affected by the fire is orographically heterogeneous, with steep slopes ( $>20 \%)$ covering most of the area and higher elevation in the north part of the Tavira municipality. Less steep terrain (between 0 and 20\%) and lower elevation are found at the southeast area of Tavira and southwest area of the São Brás de Alportel municipality, reaching zero meters at several locations (Figure 2). Maximum temperature presents annual mean values between $10^{\circ} \mathrm{C}$ and $22^{\circ} \mathrm{C}$, ranging from $25^{\circ} \mathrm{C}$ to more than $30^{\circ} \mathrm{C}$ in August, with maximum absolute temperatures around $39^{\circ} \mathrm{C}$. In the summer, relative humidity registers mean values below $65 \%$. 


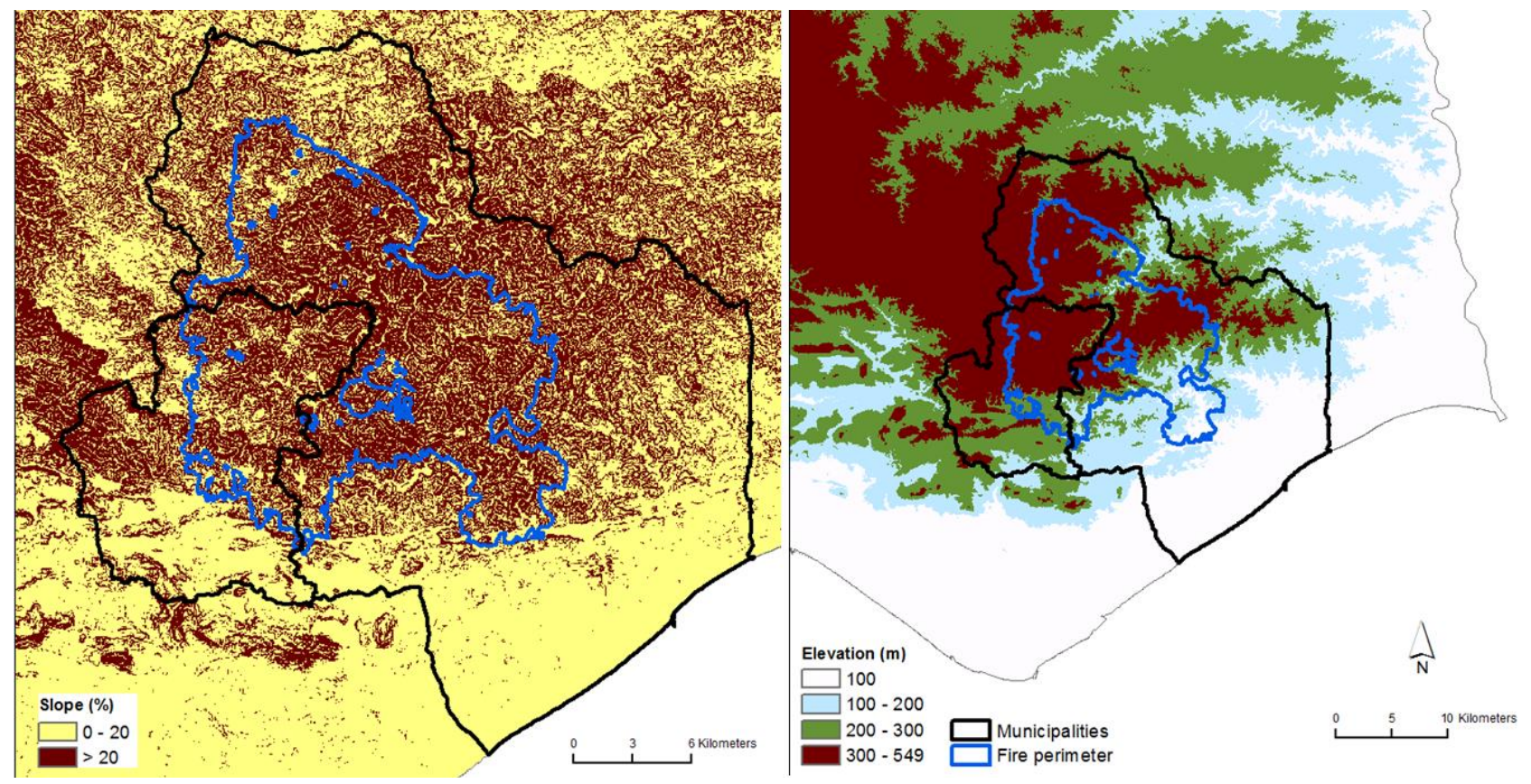

Figure 2. Slope and elevation maps of the study area

In 2012, the precipitation was $45 \%$ below the normal record and all the study area was in extreme drought condition, with a soil water content value below $10 \%$ at the time of the fire. The vegetation moisture content was estimated to be less than $80 \%$ for woody fuels, from 5 to $7 \%$ for fine fuels, and no higher than 7\% for herbaceous fuels. In addition, the years of 2010 and 2011 experienced above average precipitation favoring vegetation growth and fuel build up. Fire danger as per the Canadian Fire Weather Index (FWI) System was Extreme with FWI=56.7 as the average for the most active period of the fire.

The Tavira wildfire was first reported at $14 \mathrm{~h} 10 \mathrm{July} 18^{\text {th }}$, contained at $17 \mathrm{~h} 46$ on $\mathrm{July} 21^{\text {st }}$ and considered completely extinguished on July $27^{\text {th }}$. Two important stages for our analysis are identified and will be briefly described.

First stage - Initial development, from 14 h10 July $18^{\text {th }}$ to 18 h00 July $19^{\text {th }}$ (approx. 28 hours)

The fire burned approximately 5000ha (approx. 20\% of total burned area) under favorable conditions for fire spread: fuel moisture was very low, allowing for embers (projected up to hundreds of meters) to ignite and result in multiple spot fires; weak wind but highly variable in direction, causing the fire to spread in every direction and making the initial attack difficult. Fire suppression was hampered by the unfavorable steep, rugged terrain. The unfavorable steep, rugged terrain hampered fire suppression. The fire started spreading through steep slopes along the Ribeira de Odeleite basin (Figura 3).

Second stage - conflagration with very fast spread towards south, from $18 \mathrm{hOO} \mathrm{July} 19^{\text {th }}$ to 1 hOO July 20 (approx.7 hours)

The fire reached the Ribeira de Odeleite basin and turned into a major conflagration, turning fire suppression extremely difficult. Several factors led to this loss of control. Reaching Ribeira de Odeleite, the fire increased its intensity by aligning with canyons and steep slopes, spreading alongside the basin. An increase in wind speed led to fast and intense fire growth towards south with a 10km fire front with two advanced fronts heading west and east to the São Brás de Alportel and the Tavira municipalities respectively. Spotting occurred up to two kilometers from the fire front. Fire spread between this stage and the final southern limit in approximately 7 hours.

\subsection{Simulation framework}

The spatial resolution of the gridded data was set to 100 meters and the temporal resolution was set to 1 hour time step for both models. Fire suppression activities were not simulated in either model. In 
FARSITE, fire acceleration and No-Wind No-Slope rate of spread for the spread rate of backing fires, were enabled during simulations. Rate of spread adjustment was set to 1.0 (no adjustment). Three different time steps (Table 2), i.e. burning periods are simulated, based on the documented Tavira wildfire development and behavior (Figure 3).

Table 2. Time steps used to evaluate FARSITE and HFire performances.

\begin{tabular}{lll}
\hline Time step & Time of arrival & Milestones \\
\hline $\mathbf{1}$ & $2012-7-1918 \mathrm{~h} 00$ & The fire reached Ribeira de Odeleite \\
$\mathbf{2}$ & $2012-7-1921 \mathrm{~h} 00$ & $\begin{array}{l}\text { Blow-up fire behavior, until the fire front reached the area burned } \\
\text { in 2009 }\end{array}$ \\
$\mathbf{3}$ & $2012-7-201 \mathrm{~h} 00$ & The fire reached its south limit \\
\hline
\end{tabular}

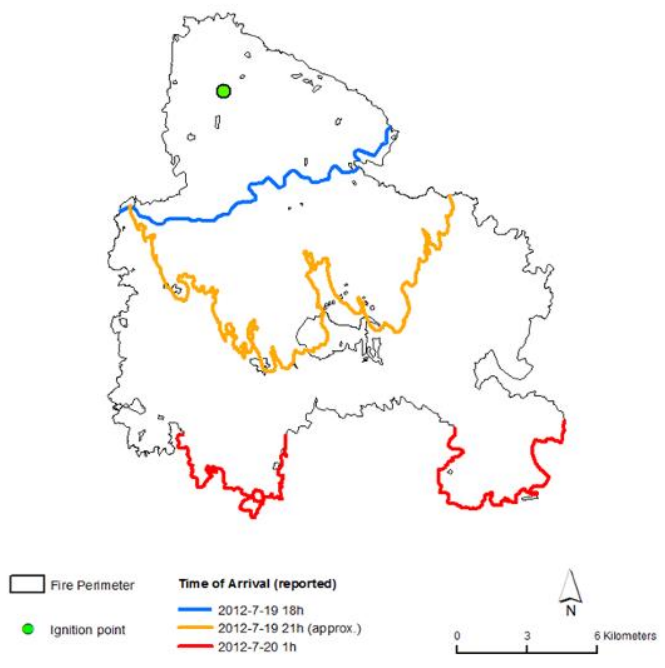

Figure 3. Spatial representation of the fire's time of arrival, for the three defined time steps (Time step 1 corresponds to Ribeira de Odeleite)

Three simulations were performed for both fire-spread models: simulation 1 - initialized at the reported ignition point (start: 2012-7-18 14h); simulation 2 and 3 - initialized with satellite-derived active-fires ignition points from MODIS passages (start: 2012-7-18 22h and 2012-7-19 14h, respectively).

\subsection{Simulations performance assessment}

The performance of the fire simulations was assessed both spatially and temporally, using the observed burned scar fire perimeter (ICNF 2012) as reference. We used the Sørensen coefficient (Legendre and Legendre, 1998) which indicates the exclusive association between the simulated and the reference burned areas (Eq. 1):

$$
\mathrm{SC}=\frac{2 \mathrm{a}}{(2 \mathrm{a}+\mathrm{b}+\mathrm{c})}
$$

where $a$ is the intersection of the burned area in the two models, $b$ is the area burned exclusively by the model, and $c$ the area exclusively burned in the actual event. A value of 1.0 indicates perfect agreement.

Other descriptors used to evaluate fire spread simulations performances were the time of arrival (TOA), rate of spread (ROS) and fire line intensity (FLI). FLI is commonly used as a measure of fire suppression capacity (Andrews and Rothermel 1982). 


\section{Results and discussion}

The Tavira wildfire spread mainly towards southeast, with winds from northeast, which is clearly observed in the simulations performed with FARSITE (Figure 4) and HFire (Figure 5). However, both models underestimated the burned area in the west part. The wind forecast predicted winds from east, which was not reflected in the wind data used to simulate the event and can explain the lack of burn in the west flank of the fire.

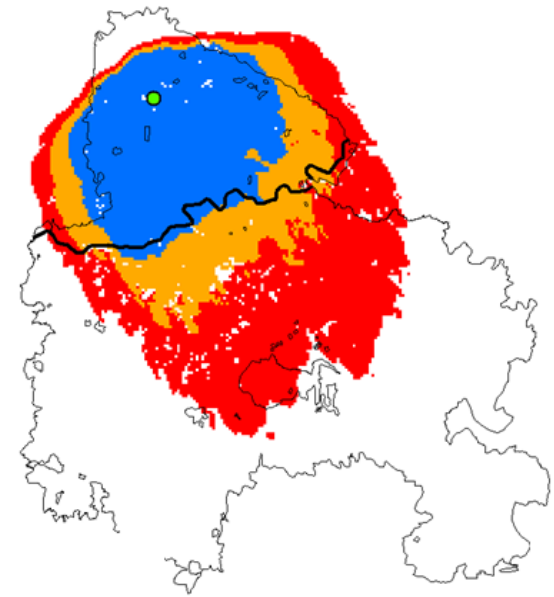

a)

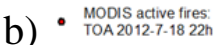

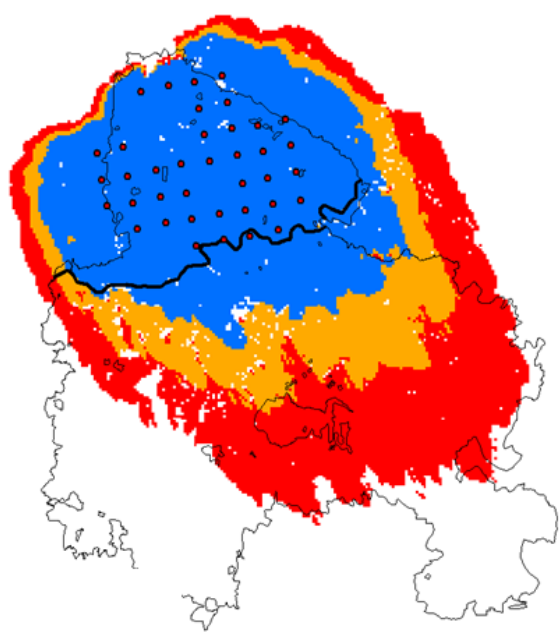

c)

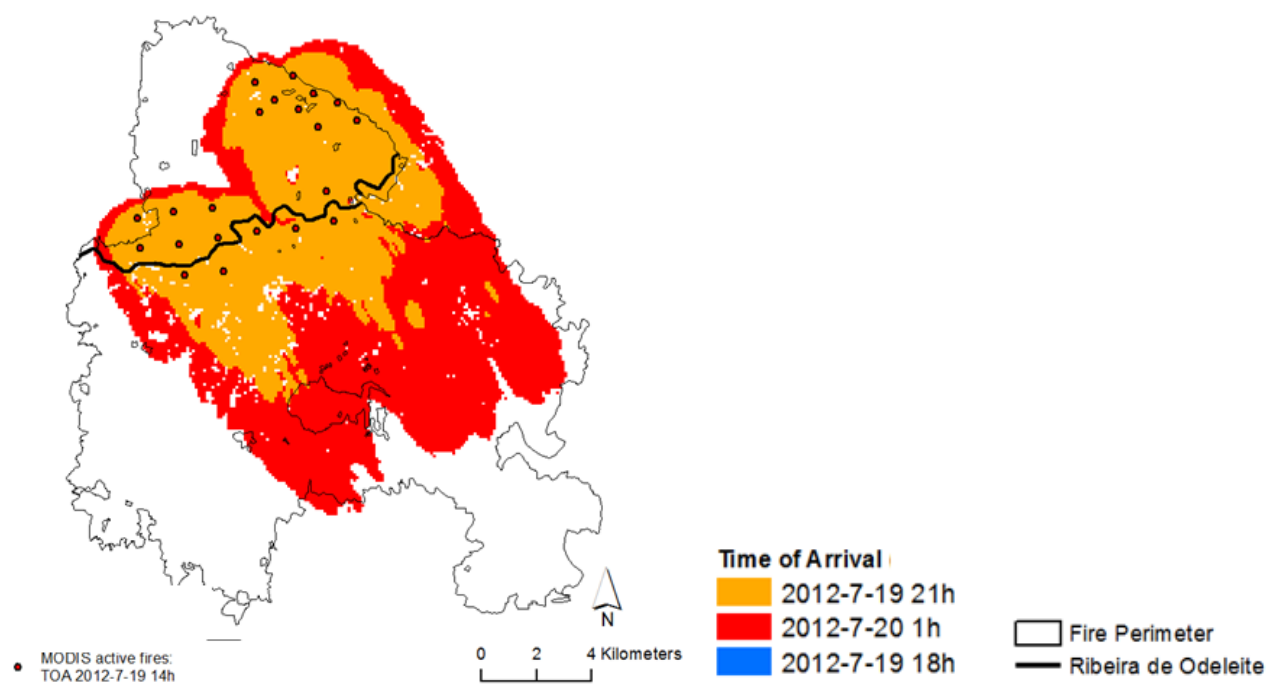

Figure 4. Spatial representation of the simulated time of arrival at the different time steps, using FARSITE. a) Simulation 1 - initialized at the reported ignition point (start: 2012-7-18 14h); b) Simulation 2 - initialized with satellite-derived active-fires ignition points (start: 2012-7-18 22h); c) Simulation 3 - initialized with satellite-derived active-fires ignition points (start: 2012-7-19 14h). 


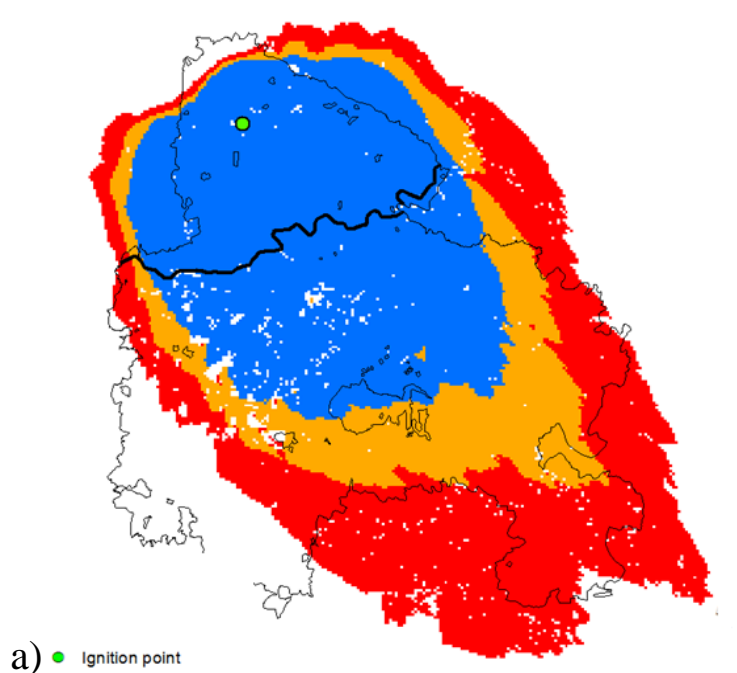

a) $\bullet$ Ignition point

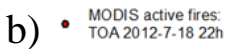

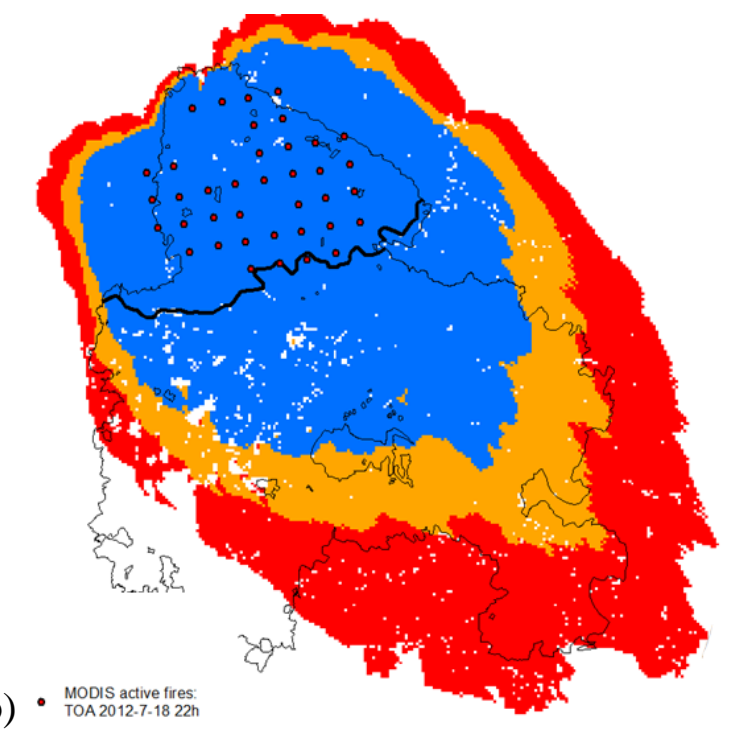

c)

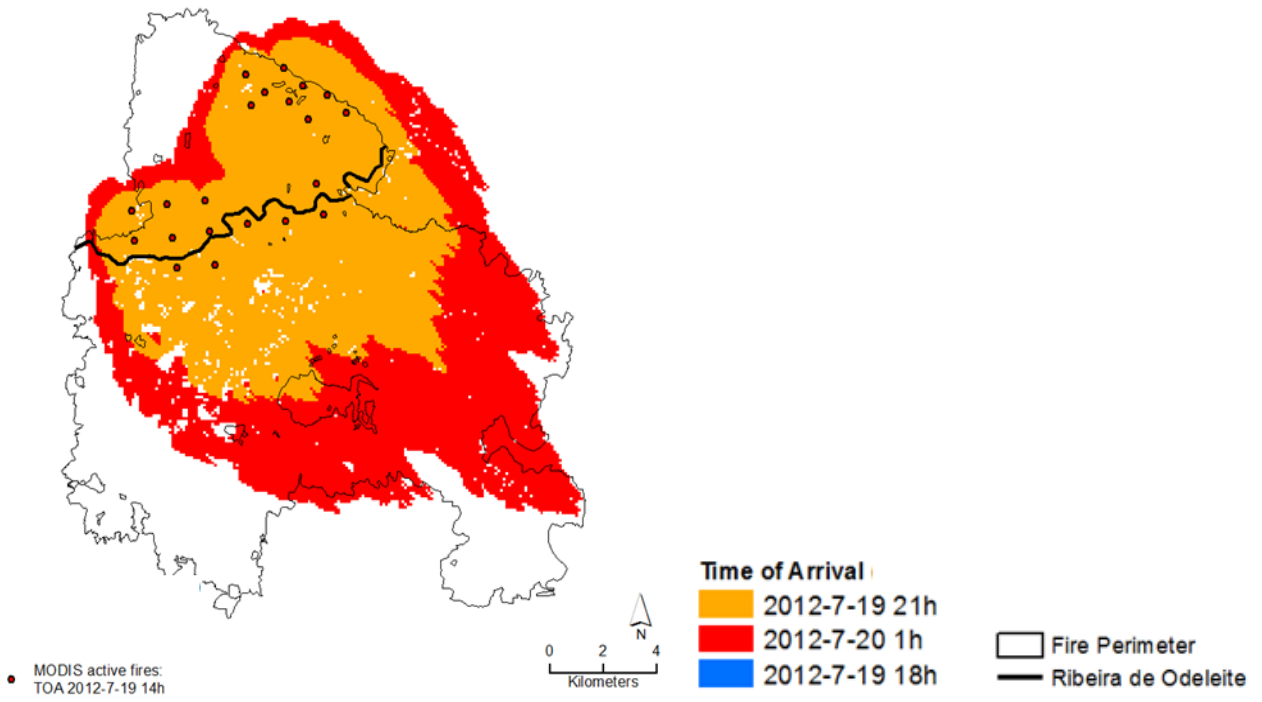

Figure 5. Spatial representation of the simulated time of arrival at the different time steps, using HFire. a) Simulation 1 - initialized at the reported ignition point (start: 2012-7-18 14h); b) Simulation 2 - initialized with satellite-derived active-fires ignition points (start: 2012-7-18 22h); c) Simulation 3 - initialized with satellite-derived active-fires ignition points (start: 2012-7-19 14h).

To evaluate FARSITE and HFire performances, the spatial and temporal agreement between the three time steps of the Tavira wildfire (Table 2, Figure 3) are compared with the three time steps obtained for each simulation with both models.

FARSITE's simulations of burned area and TOA are shown in Figure 4. FARSITE's simulation 1 shows good agreement between the simulated and observed TOA for time step 1, but both estimated TOA for time steps 2 and 3 were underestimated. As expected, starting simulation 2 with active-fires ignition points from the MODIS passage at $22 \mathrm{~h} 00 \mathrm{July} 18^{\text {th }}$, improved the estimated TOA of time step 2, now equivalent to the observed TOA for the Tavira wildfire, but continued to underestimate time step 3. Starting simulation 3 with active-fires ignition points from the MODIS passage at $14 \mathrm{~h} 00$ July $19^{\text {th }}$, underestimated both the estimated TOA for time steps 2 and 3 . These differences are probably due to different fuel models available at the start of each simulation, given that in simulation 2 the fire started spreading mainly through grass (fuel models 1 and 2), and in simulation 3 it began to spread mainly through shrub (fuel model 6). Duguy (2007) and Arca (2005) refer the need to increase the ROS adjustment factor for fuel model 6 , in order to tune fire spread growth during simulations. Since 
this fuel model covers approximately $46 \%$ of the area affected by the fire, it can be one of the reasons why all simulations underestimated time step 3, and simulation 3 in particular underestimated time steps 2 and 3.

TOA of time steps 1 and 2 were overestimated for HFire's simulations 1 and 2 (Figure 4). Starting simulation 2 with active fires ignition points from the MODIS passage at $22 \mathrm{~h} 00$ July $18^{\text {th }}$, did not change the fire's time of arrival. Setting the ignition points with active fires from the MODIS passage, at $14 \mathrm{~h} 00$ July $19^{\text {th }}$, improved the estimated TOA of time step 2, now equivalent to the observed TOA for the Tavira wildfire, but underestimated time step 3. Again, this underestimation may be related to the fuel type at the ignition location.

The SC values were calculated for each FARSITE and HFire simulations, at the defined times steps (Table 3). Results show good agreement between observed and modeled perimeters for time step 3 , for both fire spread models.

Table 3. Values of the Sørensen coefficient for time steps 1, 2 and 3, for the 3 simulations performed with FARSITE and HFire.

\begin{tabular}{lllll}
\hline & & Simulation 1 & Simulation 2 & Simulation 3 \\
\hline \multirow{4}{*}{ FARSITE } & Time step 1 & 0.29 & 0.43 & - \\
& Time step 2 & 0.41 & 0.55 & 0.40 \\
\multirow{2}{*}{ HFire } & Time step 3 & 0.60 & 0.71 & 0.68 \\
& Time step 1 & 0.60 & 0.61 & - \\
& Time step 2 & 0.72 & 0.72 & 0.53 \\
& Time step 3 & 0.73 & 0.68 & 0.74 \\
\hline
\end{tabular}

Overall results show the best TOA estimates for FARSITE and better SC values for HFire, which was also able to burn into areas that did not burn in FARSITE. When Petersen (2009) compared both models performances, concluded that HFire was better at using narrow corridors to reach additional areas of fuel. While vector-based fire growth models (like FARSITE) produce more realistic fire shapes, raster-based models like HFire can cope better with heterogeneity in fuels and weather (French et al. 1990).

For the period between time step 2 and 3, the reported ROS ranged from $20 \mathrm{~m} / \mathrm{min}$ to $25 \mathrm{~m} / \mathrm{min}$. Figure 6 shows the spatio-temporal variation of the ROS simulated by FARSITE. The simulations predict lower spread rates in the same period. The mean values of ROS for the referred time step, for simulations 1,2 and 3 , were $9 \pm 6 \mathrm{~m} / \mathrm{min}, 12 \pm 10 \mathrm{~m} / \mathrm{min}, 10 \pm 8 \mathrm{~m} / \mathrm{min}$ respectively. These values are an underestimation of the observed ROS. Nevertheless, simulation 2 presented higher ROS values when compared to simulation 1 and 3. Arca (2005) developed a custom fuel model for shrubland vegetation (maquis) that provided more realistic values of ROS when compared to the values obtained using the standard fuel models. Custom fuel models have also been developed for Portugal (Fernandes et al. 2009), and will be considered in future work to produce more realistic ROS estimates. 


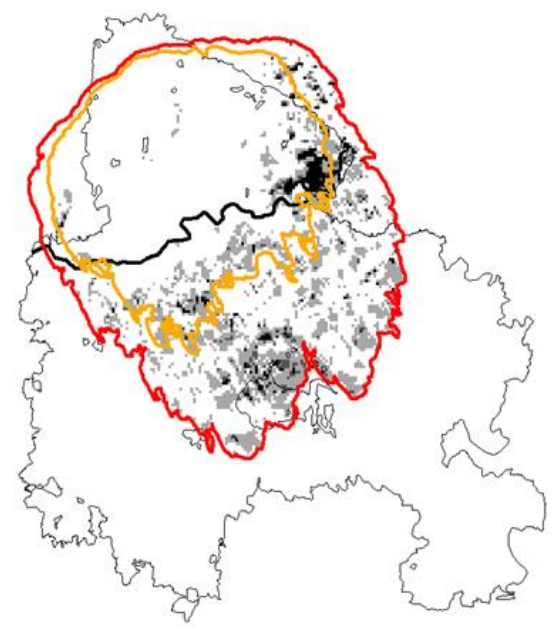

a)

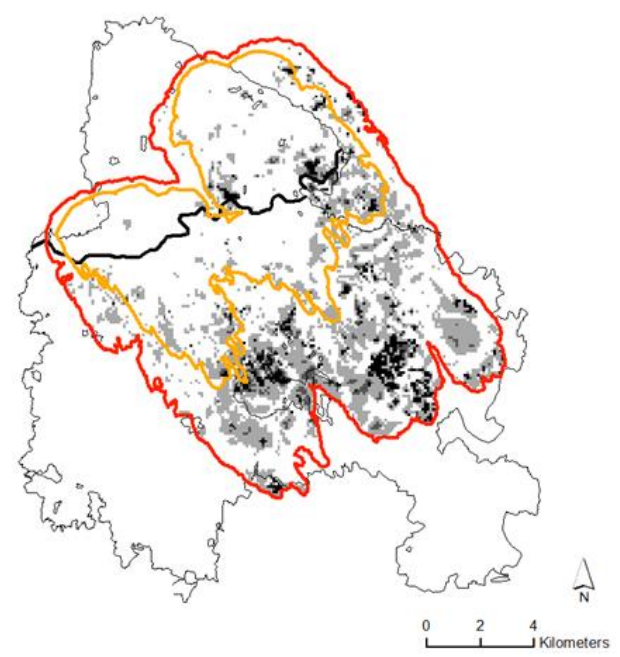

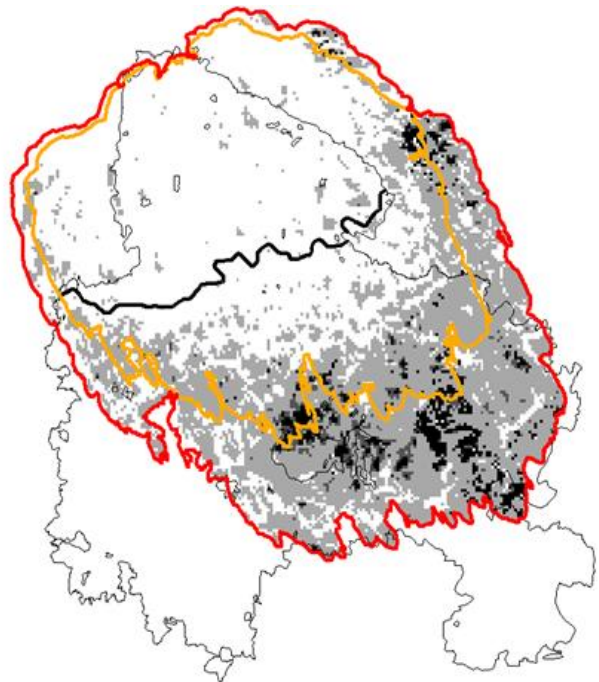

c)

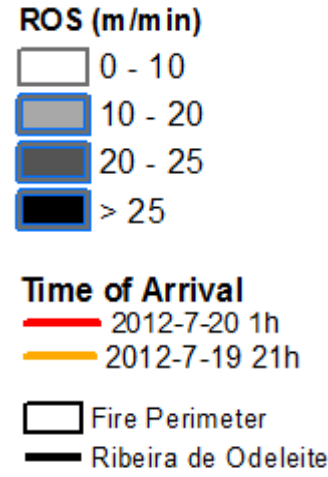

Figure 6. Spatial variation of rate of spread simulated using FARSITE. a) Simulation 1 - initialized at the reported ignition point (start: 2012-7-18 14h); b) Simulation 2 - initialized with satellite-derived active-fires ignition points (start: 2012-7-18 22h); c) Simulation 3 - initialized with satellite-derived active-fires ignition points (start: 2012-7-19 14h).

The Tavira wildfire blow-up behavior, once the fire passed Ribeira de Odeleite is apparent in all simulations, with FLI values simulated by FARSITE generally ranging from 350 to $1750 \mathrm{~kW} \mathrm{~m}^{-1}$ (Figure 7), meaning fires are too intense for direct attack on the head by persons using hand tools and equipment such as dozers, pumpers, and retardant aircraft can be effective. 


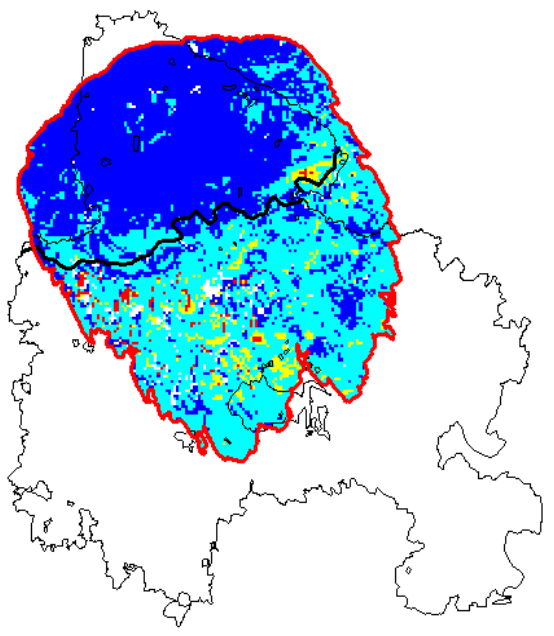

a)

c)

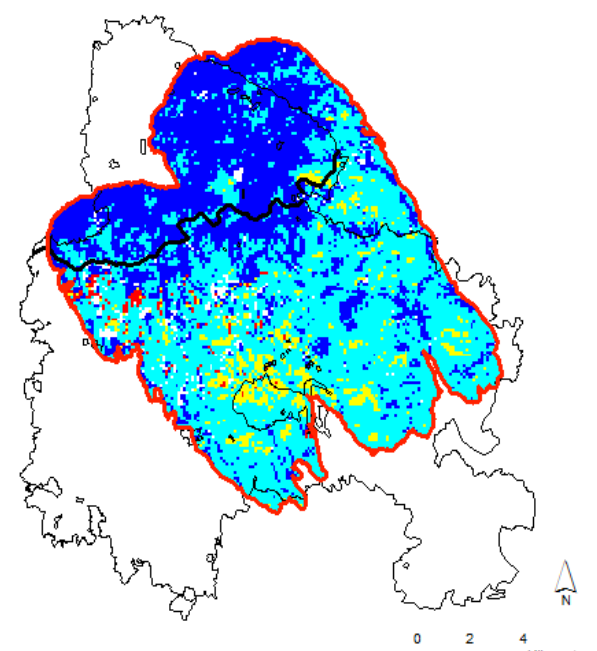

b)

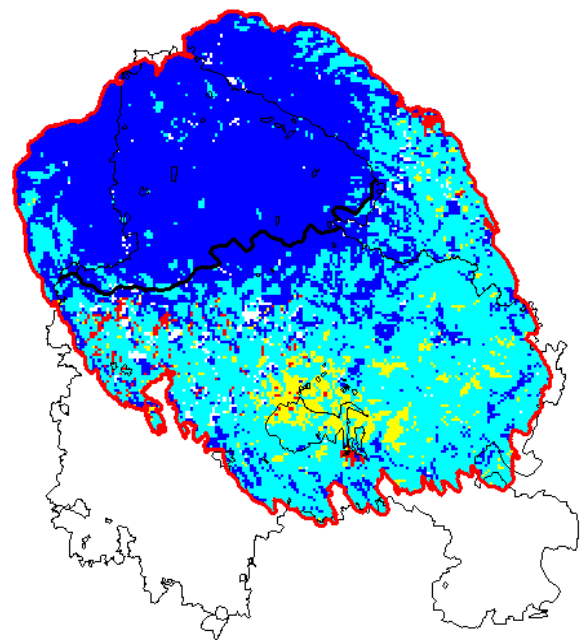

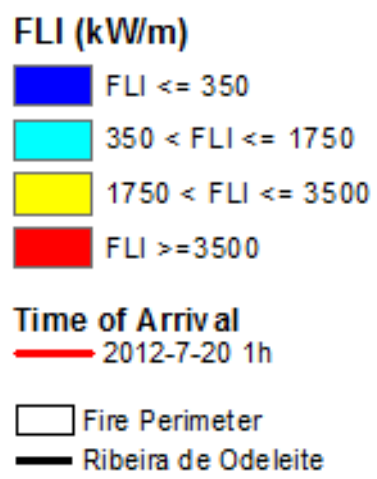

Figure 7. Spatial variation of fire line intensity simulated using FARSITE. a) Simulation 1 - initialized at the reported ignition point (start: 2012-7-18 14h); b) Simulation 2 - initialized with satellite-derived active-fires ignition points (start: 2012-7-18 22h; c) Simulation 3 - initialized with satellite-derived active-fires ignition points (start: 2012-7-19 14h).

\section{Conclusions}

In this paper we evaluated the capability of two landscape fire spread models, FARSITE and HFire, to forecast the development of the Tavira wildfire event. A first assessment of the combination of fire spread modelling and MODIS satellite derived active-fires was also performed.

Both fire spread models showed similar estimates regarding fire spread direction and shape. FARSITE produced better time of arrival estimates, i.e. for a given time step, the spatial distribution of the fire front (observed vs. simulated) were similar. HFire presented better Sørensen coefficient values and was also better able to cope with heterogeneity in fuels, reaching additional areas of fuel not burned during FARSITE simulations. However, FARSITE incorporates several other modules other than surface fire spread, taking into account phenomena (crowning and spotting) that play an important role in fire growth during extreme wildfire conditions. It also outputs important fire behavior descriptors 
other than time of arrival and burned area. FARSITE was capable of anticipating abrupt changes in rate of spread and fire-line intensity, useful to identify opportunity windows for fire control.

Combining fire spread simulations with satellite-derived active-fires allows splitting a single simulation for the entire duration of the event, into as many simulations as the number of satellite passages, attenuating the errors that propagate throughout a single simulation, since simulations are updated in time and space at each satellite passage. We conclude that this combination improved time of arrival estimates and Sørensen coefficient values for some time steps, presenting great potential for use in near-real time fire spread forecasts.

FARSITE and HFire show good capability to forecast fire spread. The combination of fire spread models with satellite data improves fire growth and behavior predictions, providing valuable supplementary information that can be used in fire management and decision support during large wildfire events.

\section{References}

Anderson HE (1982). Aids to determining fuel models for estimating fire behaviour. USDA Forest Service General Technical Report INT-122. Ogden, UT.

Andrews PL, Rothermel RC (1982). Charts for interpreting wildland fire behavior characteristics. Gen. Tech. Rep. INT-131. Ogden, UT: U.S. Department of Agriculture, Forest Serivce, Intermountain Forest and Range Experiment Station. $21 \mathrm{p}$

Arca B, Laconi M, Maccioni A, Pellizzaro G, Salis M (2005). Validation of FARSITE models in Mediterranean area. In proceeding of: Fire and forest meteorology 6th Symposium, Fire and forest meteorology.

Arca B, Duce P, Laconi M, Pellizzaro G, Salis M, Spano D (2007). Evaluation of FARSITE simulator in Mediterranean maquis. International Journal of Wildland Fire, 16: 563-572.

ANPC (2012). Relatório de Ocorrência 2012080021067 Tavira/Cachopo/Catraia. 10 de Agosto de 2012.

DiMiceli, C.M., M.L. Carroll, R.A. Sohlberg, C. Huang, M.C. Hansen, and J.R.G. Townshend (2011), Annual Global Automated MODIS Vegetation Continuous Fields (MOD44B) at $250 \mathrm{~m}$ Spatial Resolution for Data Years Beginning Day 65, 2000 - 2010, Collection 5 Percent Tree Cover, University of Maryland, College Park, MD, USA.

Duguy B, Alloza JA, Roder A, Vallejo R, Pastor F (2007). Modelling the effects of landscape fuel treatments on fire growth and behaviour in an Mediterranean landscape (eastern Spain). International Journal of Wildland Fire, 16: 619-632.

Fernandes P, Gonçalves H, Loureiro C, Fernandes M, Costa T, Cruz MG, Botelho H (2009). Modelos de Combustível Florestal para Portugal. In proceeding of: $6^{\circ}$ Congresso Florestal Nacional.

Finney MA (1998). FARSITE: Fire Area Simulator - Model Development and Evaluation. Research Paper RMRS-RP-4, Ogden, UT: U.S. Department of Agriculture, Forest Service, Rocky Mountain Research Station. 47p

Flannigan MD, Krawchuk MA, de Groot WJ, Wotton BM, Gowman LM (2009). Implications of changing climate for global wildland fire. International Journal of Wildland Fire, 18: 483-507.

Forthofer J, Shannon K, Butler B (2009). 4.4 simulating diurnally driven slope winds with windninja. USDA Forest Service, Rocky Mountain Research Station, Missoula, MT.

French IA, Anderson DH, Catchpole EA (1990) Graphical simulation of bushfire spread. Mathematical Computing and Modelling, 13: 67-71.

ICNF (2012). Recuperação da Área Ardida do Incêndio de Catraia (Julho de 2012). Relatório Técnico. Versão de 12 de Setembro. Documento em fase de elaboração.

Keane RE, Burgan R, van Wagtendonk J (2001). Mapping wildland fuels for fire management across multiple scales: integrating remote sensing, GIS, and biophysical modeling. International Journal of Wildland Fire, 10: 301-319. 
Keane RE, Cary GJ, Davies ID, Flannigan MD, Gardner RH, Lavorel S, Lenihan JM, Li C, Rupp TS (2004). A classification of landscape fire succession models: spatial simulations of fire and vegetation dynamics. Ecological Modelling, 179: 3-27.

Legendre P, Legendre L (1998). Numerical Ecology. Elsevier: Amsterdam.

Loureiro C, Fernandes P, Botelho H, Mateus P (2006). A simulation-based test of a landscape fuel management project in the Marão range of northern Portugal. Forest Ecology and Management, 234(S1).

Morais M (2001). Comparing Spatially Explicit Models of Fire Spread through Chaparral Fuels: A New Model Based Upon the Rothermel Fire Spread Equation. MA Thesis. University of California, Santa Barbara.

Moriondo M, Good P, Durao R, Bindi M, Giannakopoulos C, Corte-Real J (2006). Potential impact of climate change on fire risk in the Mediterranean area. Climate Research, 31: 85-95.

Mouillot F, Rambal S, Joffre R (2002). Simulating climate change impacts on fire frequency and vegetation dynamics in a Mediterranean-type ecosystem. Global Change Biology, 8: 423-437.

Nelson RM (2000). Prediction of diurnal change in 10-h fuel stick moisture content. Canadian Journal of Forest Research 30: 1071-1087.

Lee B, Alexander M, Hawkes B, Lynham T, Stocks B, Englefield P (2002). Information systems in support of wildland fire management decision making in Canada.

Loboda T, Csiszar I (2007). Reconstruction of fire spread within wildland fire events in Northern Eurasia from the MODIS active fire product. Global and Planetary Change, 56 (3): 258-273.

Pereira MG, Trigo RM, daCamara CC, Pereira JMC, Leite SM (2005). Synoptic patterns associated with large summer forest fires in Portugal. Agricultural and Forest Meteorology, 129: 11-25.

Petersen SH, Morais ME, Carlson JM, Dennison PE, Roberts DA, Moritz MA, Weise DR (2009). Using HFire for spatial modelling of fire in shrublands. Research Paper PSW-RP-259. Albany, CA: U.S. Department of Agriculture, Forest Service, Pacific Southwest Research Station. 44p

Petersen SH, Moritz MA, Morais ME, Dennison PE, Carlson JM. (2011) Modelling long-term fire regimes of southern California shrublands. International Journal of Wildland Fire, 20: 1-16.

Ramos A, Trigo RM, Santo FE (2011). Evolution of extreme temperatures in Portugal: reporting on recent changes and future scenarios. Climate Research, 48: 177-192.

Rothermel, RC (1972). A mathematical model for predicting fire spread in wildland fuels. Research Paper INT1143-115, USDA Forest Service, Intermountain Forest and Range Experiment Station. Ogden, UT.

Smith AM, Wooster MJ (2005). Remote classification of head and backfire types from MODIS fire radiative power and smoke plume observations. International Journal of Wildland Fire, 14 (3): 249 254.

Stratton R (2004). Assessing the effectiveness of landscape fuel treatments on fire growth and behaviour. Journal of Forestry, 102: 32-40.

Trigo RM, Pereira JMC, Pereira MG, Mota B, Calado TJ, daCamara CC, Santo FE (2006). Atmospheric conditions associated with the exceptional fire season of 2003 in Portugal. International Journal of Climatology, 26: 1741-1757.

Viegas DX, Figueiredo AR, Ribeiro LM, Almeida M, Viegas MT, Oliveira R, Raposo JR (2012). Relatório do Incêndio Florestal de Tavira/São Brás de Alportel, 18 a 22 de Julho de 2012. 